\title{
Jacobeus nos trópicos: olhares sobre a sociedade e enquadramento religioso na diocese fluminense $(1725-1773)^{1}$
}

\section{Jacobeans in the Tropics: Regards on Society and Religious Context in the Diocese of Rio de Janeiro (1725-1773)}

\author{
Evergton Sales Souza* \\ Ediana Ferreira Mendes ${ }^{\star *}$
}

\section{RESUMo}

Frei Antônio de Guadalupe, D. Frei João da Cruz e D. Frei Antônio do Desterro administraram a diocese do Rio de Janeiro entre 1725 e 1773 . Foram bispos vinculados à Jacobeia, movimento rigorista de reforma da vida religiosa que alcançou grande importância no mundo português, especialmente na primeira metade do século XVIII. O artigo pretende compreender como esses prelados que pregavam uma moral austera lidaram com a diversidade cultural e social da América portuguesa e puseram em prática suas políticas de enquadramento religioso. Busca-se descrever a presença dos bispos jacobeus na América portuguesa e, com maior detalhe, tratar das trajetórias de vida dos prelados fluminenses. Mostra-se como esses bispos se portaram no governo da diocese, como olharam para a sociedade, aten-

\begin{abstract}
Frei Antônio de Guadalupe, D. Frei João da Cruz and D. Frei Antônio do Desterro administered the diocese of Rio de Janeiro between 1725 and 1773. They were bishops linked to the Jacobeia, a rigorist movement of reform of religious life that attained great importance in the Portuguese world, especially in the first half of the 18th century. This article intends to understand how these prelates, adherents to an austere morality, dealt with the cultural and social diversity of Portuguese America and put into practice their policies of control of religious life. The aim is to describe the presence of the Jacobean bishops in Portuguese America and, in greater detail, to deal with the life trajectories of the prelates of Rio de Janeiro. The text seeks to show how these bishops behave in the diocese's government and how they perceived society,
\end{abstract}

\footnotetext{
*Universidade Federal da Bahia (UFBA), Salvador, BA, Brasil. evergtons@gmail.com <https://orcid. org/0000-0001-7466-6276>

** Universidade Federal do Oeste da Bahia (Ufob), Barreiras, BA, Brasil. edianamendes@gmail.com $<$ https://orcid.org/0000-0002-9894-9796>
} 
tando para suas percepções acerca dos pardos e negros e, por fim, para as medidas que destinaram à população escravizada.

Palavras-chave: bispos; Jacobeia; enquadramento religioso. with particular attention to their perceptions of pardos and blacks and, finally, to their measures regarding the enslaved population.

Keywords: bishops; Jacobeia; control of religious life.

Este artigo pretende analisar alguns aspectos relacionados ao governo episcopal do Rio de Janeiro no período compreendido entre 1725 e 1773, quando o bispado teve à sua frente prelados ligados à Jacobeia, um movimento rigorista de reforma da vida religiosa. À maneira de introdução, são apresentadas as características gerais do movimento e, em seguida, faz-se uma descrição sobre a presença dos bispos jacobeus na América portuguesa, atendo-se com mais vagar às trajetórias dos prelados fluminenses. Passa-se, então, à parte central deste estudo, na qual se pretende mostrar como homens de Igreja marcados pela intolerância em relação ao modo de vida daqueles que não abraçavam o rigorismo jacobeu agiram na condição de pastores diocesanos. Como percebiam as ovelhas do seu rebanho, em meio às especificidades produzidas por uma sociedade escravista, entrecruzada por gente de diversas culturas, cores e qualidades? Por onde passariam os caminhos da reforma que desejavam implantar? Essas indagações conduzem ao exame mais detido de ações marcadas pela preocupação desses prelados com a salvação das almas da população escravizada.

As fontes aqui utilizadas compõem um leque amplo e variado. Correspondências dos bispos com a coroa, relações ad limina enviadas a Roma, cartas pastorais, capítulos de visitas diocesanas e sermões pregados no Rio de Janeiro. Cada uma delas contribui, a seu modo, para a composição de um quadro inteligível, no qual se torna possível compreender a percepção dos bispos sobre a sociedade, o modo de administrar sua diocese e a reforma que desejavam promover.

\section{Sobre A JACOBEIA}

O movimento de reforma espiritual que ficou conhecido pelo nome de Jacobeia teve por fundador e inspirador o frei Francisco da Annunciação, autor das Vindícias da Virtude - obra que condensa os traços mais salientes do que se propunha como ideal de vida religiosa (Annunciação, 1725-1726). Desenvolvendo-se, a partir de fins do século XVII, como uma corrente reformadora 
no interior dos claustros de várias congregações religiosas portuguesas, a Jacobeia atingiu, na década de 1720, um novo patamar de influência na vida religiosa daquele reino. Com efeito, em 1721 eram consagrados os primeiros bispos oriundos do movimento jacobeu, cujas eleições se deviam ao novo modelo de escolha dos prelados posto em prática por João $\mathrm{V}$, que consistiu em seguir os conselhos de frei Gaspar da Encarnação nessa matéria. Com a nomeação de prelados jacobeus, a pretendida reforma da vida religiosa se expandiu dos claustros para a Igreja diocesana, sendo proposta, em diferentes níveis, à própria sociedade portuguesa, reinol e imperial (Silva, 1964; Sales Souza, 2004; Paiva, 2006).

A Jacobeia propugnava um estilo de vida austero, de rígida obediência aos preceitos evangélicos, com sinais manifestos de distinção entre aqueles que verdadeiramente abraçavam a reforma de suas vidas (os espirituais, jacobeus) e os outros (mundanos), que não acreditavam na necessidade de uma observação tão estreita e rigorosa dos preceitos cristãos. Como vários movimentos espirituais surgidos no seio do cristianismo, antes e depois das reformas da época moderna, este se caracterizou pelo rigorismo (Quantin, 2001). Isso quer dizer que jacobeus eram mais exigentes em relação ao modo como os cristãos deveriam viver. Aos religiosos exigia-se maior comprometimento no serviço de Deus, demonstrações de humildade e devoção - o que aos olhos dos antijacobeus parecia sobretudo afetação. Ecos dessa percepção antijacobeica podem-se perceber no verbete "Jacobeos" do Vocabulário de Raphael Bluteau, no qual se diz que a palavra se empregava para designar os religiosos que em conventos de frades e freiras queriam se distinguir dos outros por alguma devoção particular ou pela demonstração de uma afetada beatice (Bluteau, 1728 , v. 9, p. 504). Independentemente do que poderiam pensar os seus críticos, o fato é que o movimento foi muito mais do que uma manifestação afetada restrita a um grupo de religiosos. Por trás da Jacobeia havia todo um programa reformador. O rigor evangélico pretendido traduzia-se, por exemplo, na exigência de confissões mais frequentes e na utilização do tribunal da penitência como lugar para disciplinar e emendar a vida dos fiéis. Com muita oração mental, pregações, confissões frequentes e muita vigilância, os jacobeus desejavam reformar a vida dos cristãos em Portugal. Mais do que isso, quando bispos jacobeus foram nomeados para mitras no ultramar, o sonho da reforma deveria ser levado a todo o império português.

Para que se tenha uma ideia sobre a dimensão do movimento é preciso lembrar que prelados jacobeus foram eleitos para mitras das mais diversas partes do império, a exemplo de D. Frei Inácio de Santa Tereza, arcebispo de 
Goa (1721), D. Frei José de Santa Maria de Jesus, bispo do Cabo Verde (1721), e D. Frei Manuel Coutinho, bispo do Funchal (1725) (Alves, 2012; Trindade, 2014). O novo modelo de eleição dos bispos que vigorou a partir de 1721, sob a liderança de frei Gaspar da Encarnação e do cônego João da Mota - futuro cardeal -, também levou, entre as décadas de 1720 e 1740, ao provimento de jacobeus em quase todas as dioceses da América portuguesa.

\section{Prelados jacobeus na América portuguesa}

Desde 1725, foram providos alguns sujeitos com ligações à Jacobeia para as dioceses do Brasil. D. Frei José Fialho foi nomeado, em 1725, para o bispado de Olinda, governando-o até ser transferido para o arcebispado da Bahia, em 1738. Em Salvador, no entanto, não permaneceu muito tempo, visto que, em decorrência de uma nova promoção, retornou em 1739 para o reino. No exercício episcopal, atentou à reforma do clero, esmerando-se em estabelecer regras mais precisas para as ordenações, e à reforma dos costumes dos fiéis. Foi sucedido, em Olinda, por outro jacobeu, D. Frei Luís de Santa Teresa, que foi provido em 1738, mas não teve a mesma conduta do seu antecessor. Após envolver-se em uma série de dissídios, a coroa o convocou à corte em 1754 e nomeou um bispo coadjutor para substituí-lo (Paiva, 2008).

D. Luís Álvares de Figueiredo, arcebispo da Bahia entre 1725 e 1735, era clérigo secular e formado em Cânones pela Universidade de Coimbra. No arcebispado bracarense, ocupou diversas funções como vigário-geral de Torre do Moncorvo e do arcebispado, desembargador da Relação Eclesiástica, reitor do Seminário de S. Pedro e, desde 1716, bispo coadjutor de Braga. O seu provimento ao arcebispado da Bahia justifica-se por sua distinta experiência administrativa e pela forte influência de D. Rodrigo de Moura Teles. Todavia, a proximidade à família do cardeal da Mota e a adoção de certas medidas, como a busca por uma vida religiosa mais austera, o desejo de reformar o clero regular e controlar a atividade concionatória, permitem que se ateste a sua simpatia ao programa reformista jacobeu (Mendes, 2018, p. 500-514).

O jacobeu D. Frei Manuel da Cruz foi nomeado para a diocese do Maranhão em 1738. Anos depois, em 1745, foi transferido para o recém-criado bispado de Mariana, onde permaneceu até o seu falecimento, em 1764. No governo dessas duas dioceses, D. Frei Manuel da Cruz empenhou-se nas visitas pastorais e na criação de um seminário (Santos, 2011; Soares, 2016). No Maranhão, em 1745, outro jacobeu ainda foi eleito bispo, D. Frei Francisco de S. Tiago, permanecendo no governo até o ano de 1748 . 
Na diocese do Pará, o tomarista D. Frei Guilherme de S. José foi bispo entre 1738 e 1748, quando se aceitou sua resignação por motivo de saúde. Durante o seu governo mostrou-se um prelado zeloso, realizou pessoalmente visitas pastorais em sua imensa diocese e solicitou ao monarca a criação de várias paróquias. Foi um desses bispos jacobeus que procuraram conservar a boa relação com o governador da capitania, como se pode observar em suas correspondências com o cardeal da Mota.

O caso da diocese do Rio de Janeiro torna-se peculiar pela nomeação consecutiva de três bispos jacobeus, D. Frei Antônio de Guadalupe em 1725, D. Frei João da Cruz em 1740 e D. Frei Antônio do Desterro em 1745. A longevidade desses governos proporcionou que o bispado fluminense fosse governado por quase meio século por indivíduos vinculados a essa corrente reformadora. Por estar no centro das preocupações do presente artigo, as trajetórias e características do governo de cada um desses bispos serão abordadas mais detidamente.

D. Frei Antônio de Guadalupe nasceu em Amarante, em 1672, batizado com o nome de Antônio de Sá Cerqueira. Começou a vida seguindo os passos do seu pai, Jerônimo de Sá e Cunha, desembargador, que morreu no exercício das funções na Bahia por volta de 1688. Fez os estudos iniciais em Filosofia no Colégio de Braga e, em 1688, ingressou na Universidade de Coimbra, obtendo o título de bacharel formado em Cânones em 1695. Após habilitar-se ao serviço régio, foi nomeado juiz de fora da vila de Trancoso. Em 1701, converteu-se à vida religiosa, largou a carreira de magistrado e tomou o hábito de S. Francisco. $\mathrm{Na}$ ordem, estudou Teologia no Colégio de S. Boaventura em Coimbra e dedicou-se aos trabalhos de missionário e pregador. ${ }^{2}$

Guadalupe foi eleito bispo do Rio de Janeiro em 1722, entretanto, por motivos que desconhecemos, foi confirmado apenas em 21 de fevereiro de 1725. O prelado fluminense logo iniciou a travessia do Atlântico, tomando posse em agosto daquele ano. Desde o início do exercício episcopal, empenhou-se em implantar na diocese um projeto de reforma pautado nas máximas da Jacobeia. Uma das primeiras iniciativas foi a de apurar o estado do clero, quando convocou todos os clérigos para exame e publicou pastoral, estabelecendo critérios mais rigorosos para os candidatos ao sacerdócio. Ademais, buscou repreender os comportamentos tidos por desviantes e realizou pessoalmente visitas pastorais, alcançando boa parte dos territórios de Minas Gerais e crismando mais de 70 mil pessoas. ${ }^{3}$

D. Frei João da Cruz, cujo nome de batismo era João Salgado Castilho, nasceu em Lisboa, em 1694. Aos 19 anos de idade, decidiu abandonar a vida 
secular e tornar-se carmelita descalço, realizando a profissão religiosa em 1714. Teve uma profícua carreira dentro da ordem, foi lente de Filosofia e Teologia, prior do Convento de Santa Cruz do Bussaco e do Colégio do Carmo de Braga e, por fim, definidor geral da província de Portugal em Castela. Foi nomeado bispo pelo rei em 1739, tendo sido preconizado em 19 de dezembro de 1740, por Bento XIV. Tomou posse nos primeiros dias de maio de 1741.

De modo similar ao seu antecessor, D. Frei João da Cruz prontamente iniciou as visitas pastorais nas igrejas da cidade e publicou uma primeira carta pastoral na qual repreendia os párocos por não cumprirem com as obrigações do ofício, definia o perfil ideal dos candidatos ao sacerdócio e prescrevia normas mais rigorosas para a realização das confissões. ${ }^{4} \mathrm{O}$ prelado passaria, contudo, boa parte do seu exercício episcopal realizando visitas pastorais na região de Minas Gerais, onde enfrentou maiores resistências ao seu projeto de reforma e envolveu-se em alguns dissentimentos. Retornou das visitas, em 1744, convicto do pedido de resignação, que foi aceita por João $\mathrm{V}$, possivelmente em princípios do ano seguinte. Após sua renúncia, seguiu-se o desmembramento da diocese do Rio de Janeiro e a criação, em 1745, dos bispados de Mariana e São Paulo, além das prelazias de Goiás e Cuiabá.

D. Frei Antônio do Desterro nasceu em Viana do Castelo, arcebispado de Braga, em 1694. Optou cedo pela vida religiosa, ingressando na ordem beneditina aos 17 anos. Fez sua formação acadêmica em Teologia na Universidade de Coimbra, onde obteve o grau de doutor em 1724. Construiu uma prodigiosa carreira, inicialmente, como lente de Filosofia e Teologia no Mosteiro de Basto até ocupar as funções de abade do Colégio de Nossa Senhora da Estrela, em Lisboa, e a de reformador da província beneditina no Brasil. Em 21 de julho de 1738, foi nomeado por João V para o bispado de Angola. Eleito bispo do Rio de Janeiro em 1745, foi preconizado em 15 de dezembro do mesmo ano e tomou posse em meados de $1746 .^{5}$

O governo de Desterro no Rio de Janeiro foi extenso, perdurando até 1773. Ao longo desses anos buscou dar continuidade ao projeto de reforma do clero e dos fiéis e procurou incentivar entre seus diocesanos uma espiritualidade mais rigorista e mais próxima daquela propalada pelo movimento jacobeu. As primeiras medidas adotadas revelam esse intento. A primeira pastoral de exortação aos fiéis, lançada uma semana após a entrada episcopal, focava na mensagem da extirpação dos vícios e na vigilância sobre a conduta do clero. Outra pastoral, de 12 de agosto de 1748, estimularia a prática da oração mental. ${ }^{6}$ As constantes enfermidades impediram o exercício pleno de alguns encargos, como a manutenção das visitas pastorais, entretanto, o prelado 
nomeava visitadores com regularidade. Após as mudanças políticas ocorridas no reino com a subida ao trono de D. José e, posteriormente, a ascensão do Sebastião José de Carvalho e Melo na corte, tornando-se uma espécie de valido do rei, D. Frei Antônio do Desterro buscou congraçar-se com os novos mandantes, incorporando um forte discurso antijesuítico.

\section{RIGOROSOS MA NON TROPPO}

O rigorismo cristão quase sempre produziu uma visão de mundo intolerante. Do ponto de vista jacobeu, o projeto de emendar os costumes de todos os fiéis rendeu bons frutos, levando alguns deles à conversão. Mas também foi fonte de dissabores, pois a inflexibilidade de parte dos jacobeus levou a inevitáveis conflitos com aqueles que discordavam dos seus princípios e métodos. Não é possível, todavia, afirmar que a propensão ao conflito com os mais diversos segmentos da sociedade civil e eclesiástica fosse característica inerente aos governos dos bispos jacobeus. O caso fluminense parece ser especialmente interessante para mostrar que não houve perfeita unidade de ação na aplicação do projeto jacobeu. A trajetória de cada prelado e as diferentes conjunturas nas quais estavam inseridos determinaram atitudes de maior ou menor tolerância em relação àqueles que não se submetiam à sua visão de mundo. Também guiaram as tentativas de aplicação com maior ou menor rigor dos princípios jacobeicos, as tendências a uma ação mais política, buscando contornar possíveis conflitos com autoridades civis e ordens religiosas, ou a posturas menos flexíveis, ditadas pela imposição de um programa de reformas que criava disputas com diversos segmentos da sociedade.

Dois estudos recentes (Sales Souza, 2015; Mendes, 2018) mostram que o governo episcopal de D. Frei Antônio de Guadalupe caracterizou-se por uma atitude conciliadora e prudente. Sem abrir mão dos princípios reformadores, o prelado adotou uma postura política, evitando confrontar-se com os governantes das capitanias e com agentes da justiça régia. Evitou também disputas com o clero regular, salvo os problemas relacionados à reforma da província franciscana da Conceição, por ter sido nomeado reformador para sanar questões internas e remotas daquela comunidade. Guadalupe também buscou o acrisolamento do clero diocesano por meio das visitas pastorais e exames mais rigorosos para conceder licença aos confessores. Embora tenha procurado punir clérigos de má conduta, não há registro de maiores dissensões causadas por sua ação reformadora junto ao clero secular. 
Um pouco diferente foi o governo de D. Frei João da Cruz, que em determinadas ocasiões se mostrou menos político e, por isso, mais propenso a atrair oposições ao seu desejo de emendar os costumes. Nas Minas, durante as visitas pastorais em 1743, o bispo entrou em disputas com o ouvidor geral de Vila Rica, Caetano Furtado de Mendonça, por causa da execução de um testamento. A contenda desenrolou-se favoravelmente ao bispo, pois, em 1744, o ouvidor foi preso e enviado para o Limoeiro, em Lisboa, em razão dos excessos cometidos contra o bispo, além de outras perturbações que havia causado (Mendes, 2018, p. 214-218). O prelado também teve dissabores com alguns clérigos das Minas, em particular quando destituiu o padre Francisco Pinheiro da Fonseca da vigararia da vara da vila de Ribeirão do Carmo. A fim de manifestar insatisfação diante das ações no decorrer de sua visita pastoral, algumas pessoas retiraram os badalos do sino da igreja matriz, impedindo a saudação ao bispo ao sair da vila. Esse ato de desrespeito à autoridade episcopal gerou resposta enérgica, por meio de investigação e processo dos responsáveis. ${ }^{7}$ Independentemente dos abusos cometidos pelo vigário da vara, talvez o modo como D. Frei João da Cruz procedeu ao tirar devassa e puni-lo tenha motivado sua reação acrimoniosa. O pouco tempo que passou no governo episcopal não permite uma conclusão mais assertiva sobre a postura menos flexível do prelado, mas não é improvável que seu pedido de resignação do bispado - cujo documento original não encontramos em nossas pesquisas - pudesse resultar do reconhecimento de suas limitações para lidar com os problemas inerentes à administração de uma diocese ultramarina.

O longo episcopado de D. Frei Antônio do Desterro se desenrolou, majoritariamente, no reinado de D. José, numa conjuntura consideravelmente diferente daquela vivida por seus dois antecessores. Nos anos 1750, após a querela do sigilismo, os jacobeus haviam perdido bastante força, e as mortes do cardeal da Mota e de frei Gaspar da Encarnação contribuíram, sem dúvida, para enfraquecer o movimento na corte. O próprio movimento parece cindir-se em dois grupos quanto às novas tendências encampadas pelo novo reinado a partir da segunda metade da década de 1750. De um lado, aqueles que, a exemplo do bispo de Coimbra, D. Miguel da Anunciação, mostrar-se-iam avessos às políticas regalistas que ameaçavam, em seu entender, o poder eclesiástico; doutro lado, jacobeus que aderiram, seja por convicção, seja por oportunismo, ao novo governo, apoiando suas políticas (Sales Souza, 2004, p. 201-234; Paiva, 2011, p. 393-417). Desterro fez parte desse último grupo e demonstrou grande empenho, por exemplo, na perseguição aos jesuítas de sua diocese. Uma observação de conjunto sobre seu episcopado tende a mostrar 
que foi um prelado suficientemente político para buscar apoios junto à corte e evitar situações de confronto com as autoridades civis. Os maiores conflitos em seu governo decorreram de problemas com a definição das fronteiras do bispado, que havia perdido áreas importantes, do ponto de vista da riqueza demográfica e material, para as dioceses de Mariana e São Paulo (Fonseca, 2003, p. 120-121; Britto, 2018, p. 66-70; Mendes, 2018, p. 227-231). No que diz respeito ao clero diocesano, Desterro deu continuidade à política de seus antecessores, insistindo em preocupações características da Jacobeia, como os cuidados com a confissão, com o exame de consciência e a prática da oração mental. Embora tenha buscado a emenda dos costumes do clero, bem como sua melhor formação, como se vê em sua carta pastoral de 12 de outubro de 1762 , na qual procura corrigir a conduta dos seminaristas de S. José, o bispo fluminense não parece ter enfrentado maiores resistências. Uma das poucas vezes em que teria gerado insatisfação foi quando nomeou um sobrinho para o curato da Sé. Na ocasião, em janeiro de 1753, foi enviada ao Conselho Ultramarino uma súplica, assinada por alguns súditos, na qual contestavam aquela e outras nomeações de familiares do bispo para benefícios eclesiásticos em detrimento dos naturais do bispado. ${ }^{8}$

De modo geral, os governos dos três prelados jacobeus não foram marcados por relações conflituosas com as autoridades civis ou com o clero diocesano. As dissensões com um ouvidor e alguns clérigos havidas nas Minas em tempos de D. Frei João da Cruz não seriam suficientes para caracterizar seu curto governo como conflituoso, ainda que possam sugerir sua menor habilidade política.

\section{Olhares JACOBEUS SOBRE A SOCIEDADE LUSO-AMERICANA}

Em alguns registros deixados por esses bispos também é possível conhecer um pouco sobre a percepção que tinham da população de suas dioceses. Numa carta de junho de 1726, dirigida ao cônego João da Mota, D. Frei Antônio de Guadalupe notava que eram muitos os que se achavam dignos das maiores honras por exercerem algum ofício régio. Para ele, aquela sociedade estava marcada por uma vontade excessiva - e descabida, no seu entender - de distinção. Também falava sobre os pobres, que eram inúmeros, assim como os pedidos de esmolas, a ponto de dizer que para atender ao que se pedia seria necessária a renda do arcebispado de Évora. Noutra passagem, resumia bem o que pensava sobre os habitantes de sua diocese. Parecia-lhe que era gente "enganosa e nada segura”, não havendo em quem confiar. Dizia: "isto por cá 
é tudo uma patarata, muita fachada, muita vaidade e muito engano". Em seu entendimento a terra parecia infundir sensualidade "e os incentivos são contínuos na desnudez das negras, que são muitas e no conserto e asseio de outras que vivem do ruim trato, e chamam andar na rua, a quem os senhores não contradizem pelo lucro que lhe pagam". Além das negras, havia as mulatas pelas quais se pagavam 500 mil réis ou até mais com o objetivo de as usarem sexualmente. Os homens, dizia, luzidíssimos no trato, "e é o que os lança a perder e por isso nas Minas não há pagar dívidas, porque por muito ouro que tirem, não chega para tanto, com que quem mais rico é lá, mais deve". ${ }^{9}$

D. Frei João da Cruz não fazia melhor juízo da gente de sua diocese. Numa correspondência do referido episódio do roubo dos sinos, o prelado revelava a sua visão sobre aquelas terras, dizendo que todos ali viviam "com pouco ou nenhum conhecimento de Deus e sua Igreja, os brancos pela sua absoluta rebelião e ruins princípios que a estas partes os trouxeram; os mulatos por amigos da novidade e de más inclinações; e os pretos pela sua rusticidade e ignorância". ${ }^{10}$

Por fim, não conhecemos testemunhos mais diretos de D. Frei Antônio do Desterro sobre o modo como via a sociedade, mas, juntando algumas informações esparsas é possível ter uma ideia geral sobre o assunto. Numa missiva sobre a administração dos índios, por exemplo, chamava a atenção para a pouca piedade daqueles que tratavam de distrair escravos negros com índias, e índios com escravas negras, a fim de, por esse artifício, fazê-los trabalhar sem custos para sua administração. Resultava que tais administradores, afetando motivação religiosa, incentivavam tais casamentos para que, pelo vínculo do matrimônio, ficassem os indígenas presos e ligados ao seu serviço. Numa outra correspondência, na qual tratava da fundação de um recolhimento, expunha sua preocupação com as mulheres depravadas que abundavam em sua diocese. Dizia que em suas visitas sempre colhia daquelas mulheres "a universal desculpa de que a necessidade a que se viam reduzidas pela pobreza, as obrigava a continuar no pecado de que totalmente se apartariam se tivessem outros meios para se sustentarem e vestirem". ${ }^{11}$ A junção dessas notícias deixa entrever que a percepção de Desterro sobre a sociedade fluminense não deveria estar muito distante daquela de seus antecessores.

\section{PARDOS E NEGROS}

Pode-se afirmar que a maneira de esses bispos jacobeus perceberem as cores e raças dos homens não apresenta verdadeira peculiaridade em relação 
às percepções mais geralmente compartilhadas pela elite portuguesa. Em seu livro sobre as nobrezas do novo mundo, Ronald Raminelli traz uma excelente reflexão sobre a questão das cores, raças e qualidades no mundo português do Antigo Regime (Raminelli, 2015, p. 207-239). Mostra, por exemplo, que num mundo hierarquizado, a cor da pele não estava dissociada dos princípios que buscavam demarcar as diferenças de qualidade entre as pessoas. Muitos testemunhos evidenciam que era comum vincular a cor da pele aos comportamentos, associando os hábitos brancos à nobreza. Mas nem todos compartilharam de uma visão demasiado preconceituosa. O Padre Antônio Vieira, por exemplo, manifestou em alguns sermões seu desacordo em apresentar a cor da pele como um elemento a provar a natureza inferior ou superior dos homens. No sermão da Epifania, pregado na capela real, em 1662, Vieira dizia:

Dos magos que hoje vieram ao presépio, dois eram brancos e um preto, como diz a tradição: e seria justo que mandasse Cristo que Gaspar e Baltasar, porque eram brancos, tornassem livres para o Oriente, e Belchior, porque era pretinho, ficasse em Belém por escravo, ainda que fosse de São José? Bem o pudera fazer Cristo, que é senhor dos senhores; mas quis nos ensinar que os homens de qualquer cor todos são iguais por natureza e mais iguais ainda por fé, se creem e adoram a Cristo. (Vieira, 1685, p. 533)

A mesma refutação a respeito da cor da pele, determinada pela natureza, como justificativa do domínio e ainda como prova de superioridade de uns homens sobre outros encontra-se no "Sermão XX do Rosário", como bem descreveu e analisou Raminelli (2015, p. 222-224). Contudo, a posição de Vieira parecia, de fato, confrontar uma visão preconceituosa predominante, que concebia na cor branca da pele uma inata superioridade em relação às demais.

Bom exemplo desse preconceito de cor pode-se ver numa carta de João Pereira Ramos de Azeredo Coutinho ao seu irmão Francisco de Lemos Faria Pereira Coutinho, datada de 21 de agosto de 1775. O testemunho é tanto mais interessante por se tratar da correspondência de dois homens da elite fluminense que tiveram carreiras brilhantes no reino, tendo sido, o primeiro, procurador da Coroa e, o segundo, reitor da Universidade de Coimbra e bispo daquela diocese. Na carta, Azeredo Coutinho reportava ao irmão a situação de um jovem parente, José Joaquim da Cunha de Azeredo Coutinho, futuro bispo de Olinda, que desejava estudar na Universidade e seguir vida religiosa. Descrevia, elogiosamente, as habilidades do rapaz de 32 anos, mas a descrição física chama a atenção: "a figura não é má, posto que na cor seja bastantemente trigueiro” (Bandeira, 2017, 
p. 58). A cor era, portanto, um defeito, uma marca desfavorável, um inconveniente sinal de mulatismo. Noutra carta, Azeredo Coutinho tratava de um sobrinho, Vasco Fernandes Coutinho, e dizia que embora não fosse bonito também não era "hediondo, e é claro, o que nele é mais estimável por excluir toda a presunção que daria lugar a cor trigueira, suposto ser ilegítimo" (Bandeira, 2017, p. 150). Assim, explicitava os problemas colocados pela cor parda, ao tempo em que salientava a vantagem de se ter a pele branca. ${ }^{12}$ Essas passagens expressam como, geralmente, as elites encaravam os frutos da miscigenação, não apenas mostrando o preconceito em relação aos pardos, mas também reforçando o estigma de inferioridade dos negros.

O mais eloquente testemunho sobre a concepção de um prelado jacobeu acerca desses homens de cor aparece em alguns escritos de D. Frei Antônio de Guadalupe, em particular num sermão pregado no Rio de Janeiro, em 1737. $\mathrm{Na}$ ocasião, lembrava das palavras que, através de Jeremias, Deus teria dirigido aos moradores da Judeia: "Pode um etíope mudar de cor ou um leopardo as suas pintas? Podeis acaso fazer o bem, vós que estais acostumados ao mal?" (Guadalupe, 1749, p. 13, 23). Com esse versículo o pregador desejava ressaltar a dificuldade de emendar os costumes de pecadores inveterados. Primeiro chamava a atenção para a dificuldade na interpretação da passagem, pois a pele negra do etíope, bem como as manchas do pardo eram naturais, portanto, não podiam mudar. Já os pecados da Judeia eram manchas morais, que podiam ser apagadas. A razão da comparação, entretanto, estava nos maus costumes daqueles pecadores empedernidos, tornando praticamente impossível a sua correção. Acrescentava:

E notai que bastando para exemplo a impossibilidade da mudança do pardo, acrescentou Deus a impossibilidade da mudança do Etíope. E por quê? Porque a circunstância de serem os maus costumes aprovados não se expressa, ou verifica no Pardo, e verifica-se no Etíope. Fazei a experiência que eu já fiz. Perguntai a um negro, qual é melhor: o ser negro ou ser branco? E vos há de responder, que melhor ser negro. Assim são os de maus costumes, que estão tão bem achados com eles que os têm por melhor do que não tê-los. (Guadalupe, 1749, p. 346)

Sem deixar dúvida quanto à superioridade dos brancos, o bispo parece estabelecer uma relação direta entre ser negro e ter maus costumes, exprimindo uma visão preconceituosa que era majoritária entre a elite branca. Também é interessante constatar a forma como tratou os pardos nesse passo do sermão, deixando entender que não estariam dispostos a teimar sobre o assunto. 
Talvez, por trás da retórica do pregador, estivesse a ideia fundada na observação de que para os pardos não interessava a insistência na diferença da cor. Afinal, silenciá-la poderia ser uma maneira de afastar-se dos traços que os aproximavam dos negros. ${ }^{13} \mathrm{O}$ certo é que o preconceito de Guadalupe em relação aos mulatos pode ser visto de maneira ainda mais crua na passagem de uma correspondência em que comunica ter recebido a visita de "um pároco de aldeia de 82 anos de idade e de grande capacidade e letras, como que tudo desmente a cor que tem porque é mulato". ${ }^{14}$

No âmbito deste estudo, importa, sobretudo, assinalar que o preconceito de cor não desembocou em uma atitude de menosprezo ou desinteresse pelos fiéis inferiorizados. Em sermões e em capítulos de visitas, tanto Guadalupe como seus sucessores jacobeus demonstraram grande preocupação em relação à administração dos sacramentos aos escravos. O mesmo Guadalupe, num sermão do terceiro domingo da Quaresma, pregado em 1732, no Rio de Janeiro, lastimava a facilidade com que se mandava uma multidão de escravos para desobrigarem-se da Quaresma, recomendando-lhes pressa para que não viessem a faltar ao serviço:

Sem lhes dar tempo para se disporem, sem lhes dar lugar para se examinarem nem lhes ensinarem com a hão de fazer. E o pior é que para se confessarem todos logo sem prejuízo do serviço, lhes buscam um confessor da algibeira, que faça com brevidade aquela rasoura. Então, fulano tem tantas peças? Sim tem; mas o mal é que quanto mais peças tem, mais peças faz à sua consciência. Ah pobres escravos, alguns, em que mãos viestes dar! Ah, tiranos senhores, que conta havereis de dar das suas almas? (Guadalupe, 1749, p. 264)

Se o preconceito de cor não deu lugar ao desprezo em relação ao negro escravizado, também não se deve pensar a passagem acima referida como a manifestação de um pensamento humanista. O problema aqui se coloca em termos religiosos. A cor e a condição de escravo não anulam o fato de serem cristãos. E, enquanto escravos, seus senhores são responsáveis, em alguma medida, pelos cuidados espirituais que lhes são devidos. E, sobretudo, são ovelhas do rebanho do bispo pregador que, portanto, não pode descurar do seu devido pasto espiritual, da salvação de suas almas.

Noutro contexto, em carta dirigida ao monarca, em 1743, na qual descreve as afrontas que sofreu nas Minas e pede a punição dos envolvidos, D. João da Cruz refere-se aos brancos como rebeldes, aos mulatos como inclinados ao mal e aos pretos como rústicos e ignorantes. ${ }^{15} \mathrm{Na}$ percepção carregada de 
preconceito que emerge das suas palavras, pode-se pensar que o tratamento dado aos brancos se prende ao fato de seus principais adversários, aqueles que o trataram com maior desacato, fazerem parte desse grupo. Nessa missiva, chama também a atenção o modo como o prelado lastima ver a excomunhão ser temida por "um rude negro" e desprezada pelo branco. Indignava-se com aquilo que considerava a inversão das coisas, um mundo de ponta-cabeça onde os negros se faziam mais tementes a Deus e à Igreja do que os brancos. Mas em sua indignação evidenciava, também, seu olhar em relação à população escrava que, não obstante sua rusticidade, era parte importante do rebanho que ele, enquanto pastor, deveria conduzir à salvação.

\section{Medidas Relativas À POPUlaÇão ESCRAVIZADA}

Os comportamentos das populações de ascendência africana e escravizada não estavam em sintonia com a conduta dos cristãos perfeitos, virtuosos e devotos que os prelados jacobeus almejavam. Embora desejassem promover a reforma de sua diocese, disciplinar os comportamentos, enquadrar as devoções, conduzindo suas ovelhas à salvação, eles foram confrontados a realidades que exigiam mais paciência e brandura do que mera imposição de modelos. Com efeito, diante de populações recém-conversas ou em vias de conversão ao cristianismo - caso dos índios e da população escravizada -, o problema que se colocava era o de ensiná-las a doutrina e consolidar seus laços com a fé cristã e com a Igreja. Assim, os bispos percebiam os escravos como rudes e, quando tratavam da sua prática religiosa, dirigiam-se aos senhores de escravos, ou aos párocos e capelães para que instassem e repreendessem os senhores que não cumprissem as determinações do bispo. Vale salientar que os bispos reconheciam os párocos como principais agentes do disciplinamento, pois eles é que poderiam atuar mais diretamente no enquadramento religioso dos seus fregueses. Isso ajuda a entender por que os jacobeus preocupavam-se tanto com a reforma do clero secular e o controle sobre as atividades dos párocos, pregadores e confessores. O clero secular tinha a função primordial de servir como espelho e inspirar nos fiéis uma conduta religiosa mais austera.

Na carta pastoral de 16 de setembro de 1728, escrita após a realização das visitas pastorais, D. Frei Antônio de Guadalupe alvitrava aos párocos e capelães a obrigação de ensinar a doutrina aos escravos, que deveriam estar "acompanhados dos seus feitores (por se conhecer a desculpa que nisto dão)”, e estabelecia uma pataca de coima aos donos. Ainda constrangia os senhores a enviar os seus escravos para ouvir missa e condenava o trabalho em dias santos. $\mathrm{O}$ 
controle caberia aos párocos e capelães, que deveriam fazer um rol daqueles obrigados a comparecer às celebrações no domingo e dias santos. No tocante aos amancebamentos, Guadalupe utilizava como instrumento de coação justamente a "denegação de sacramentos". Determinava aos párocos e capelães que impedissem os senhores que consentiam o concubinato dos escravos e escravas "até que os façam contrair matrimônio, ou se apartem totalmente". Ademais, os donos eram acusados de lenocínio das suas escravas e o prelado orientava os párocos e capelães a cuidarem dos "que têm escravos em venda, vivendo desonestamente e os trazem com tabuleiros, da mesma sorte se emendem dessa culpa”. Trata-se de tema sobre o qual Guadalupe insistiria num sermão proferido na Sé do Rio de Janeiro, em 1737. Reportando-se às escravas que mercadejavam, mas que também vendiam seus corpos, dizia aos senhores:

Vós vedes em casa o preço deste exercício das vossas escravas, porque vedes os seus filhos e os adornos que não lhes destes; pois como vos podeis livrar, de que consentis no seu exercício e aprovais o seu pecado? E tendes por pecado este vosso consentimento? Já vejo que dizeis que não; porque tendes na ponta da língua, que assim vos é necessário para sustentar a vossa casa, e que este é o costume de todos, ou o costume da terra, e como tal é licito e obrais bem.

A reprimenda do bispo aos senhores de escravos é um eloquente testemunho de como a escravidão era a porta entreaberta que permitia toda sorte de abusos nada condizentes com os ideais cristãos professados pela sociedade colonial.

Na carta pastoral de maio de 1742, D. Frei João da Cruz também prescrevia aos párocos o ensino da doutrina cristã por pelo menos uma hora e arrogava aos párocos a função de coagir os "pais de família" a enviarem "seus filhos, criados e servos e escravos". ${ }^{16}$ Noutro passo, comerciantes eram advertidos a não venderem ou mandarem seus escravos trabalharem em dia de preceito. Os senhores eram igualmente admoestados a conceder o sábado para que os escravos trabalhassem nas suas roças, reservando o domingo para as missas. ${ }^{17}$

O tema da parca doutrinação aos escravos já havia aparecido nos capítulos de visitas deixados por Guadalupe nas igrejas de Minas Gerais, quando constatou a grande "ignorância da doutrina cristã" e exortou o ensino em todos os domingos e dias santos. O ineficiente ensino da doutrina impactava a realização dos batismos, visto que os párocos tinham por obrigação avaliar o conhecimento da doutrina antes de administrar o sacramento. Na vila do Carmo, 
em 2 de dezembro de 1726, Guadalupe advertiu os senhores que mandavam seu escravo ser batizado em outras freguesias, em virtude, provavelmente, de “o próprio pároco não o achar com a doutrina necessária”. Segundo o prelado, além de grande "dano das almas", essa prática causava enorme confusão sobre as jurisdições de cada freguesia.

O tema dos concubinatos foi abordado por Guadalupe nos capítulos de visita. Em visita à vila do Carmo, admoestava veementemente os seus diocesanos contra a prática dos amancebamentos, inclusive com as escravas. Neste caso, alertava que elas deveriam ser mandadas embora, pois "o preço e custo da escrava não faz causa alguma para deixar de ser [e]vitável a ocasião nem a perda temporal ser desculpa para se perder a alma do Senhor".

Guadalupe ainda se posicionou contra as práticas religiosas dos africanos, sobretudo daqueles oriundos da Costa da Mina. O bispo asseverava ter sido informado de que os escravos guardavam relíquias e juntavam-se à noite "em vozes com instrumentos em sufrágios de seus falecidos”, ou sentavam-se em tabernas com muitas comidas e bebidas. Os párocos e capelães eram incumbidos de "desterrar estes abusos" e condenar "qualquer pessoa que em sua casa recolha, ajude ou favoreça nestas superstições” (Rodrigues, 2004, p. 35-48).

Nas visitas pastorais a Minas Gerais, D. Frei João da Cruz reforçou a importância do ensino da doutrina cristã, da administração dos sacramentos da eucaristia e extrema-unção, estabelecendo novamente condenações aos senhores por deixarem faltar aos escravos “os sacramentos não só na hora da morte mas também em vida para que no juízo final não tenham mais de que dar estreita conta dos pecados dos seus escravos". Contrapôs-se ao trabalho dos escravos nas minas nos domingos e dias santos e recomendava, mais uma vez, aos párocos, capelães e demais sacerdotes que constrangessem os senhores a fornecer o básico de "vestido e sustento para a sua vida ou um dia de semana que não seja domingo ou dia santo livre" para que eles alcançassem a própria sustentação (Rodrigues, 2004, p. 60-70).

D. Frei Antônio do Desterro destinou uma longa pastoral para tratar do tema da doutrinação, estabelecendo penas aos párocos e capelães que não fizessem práticas e doutrinas aos seus fregueses, e instava os pais, senhores, tutores e mestres de escolas a obrigar a assistência dos seus "filhos, escravos, pupilos e discípulos". O bispo relembrava os párocos da obrigação primordial de realizar práticas espirituais aos fregueses para que "se movam, e facilitem para adquirir e procurar os meios eficazes da sua salvação" e, mais adiante, frisava a importância de ensinar a doutrina cristã e repartir o "pão espiritual aos rústicos, ignorantes, e párvulos”. Já nas nomeações dos visitadores, o 
prelado recomendava que aplicassem a pessoas pobres, miseráveis e, entre elas, as escravizadas, somente penas espirituais como as "penitências internas de reza, jejuns" e outras externas como o "trabalho, serviço em alguma igreja que eles possam satisfazer sem dispêndio", além de subdelegar a alguns visitadores as faculdades de dispensar os impedimentos de matrimônio dos índios, escravos, pobres e miseráveis.

Algumas instruções não mencionavam expressamente as populações escravizadas e de ascendência africana, contudo, elas eram certamente o alvo. Tanto Guadalupe quanto Desterro, por exemplo, posicionaram-se contra os ajuntamentos, bailes, batuques e saraus que congregavam os dois sexos em homenagem a Nossa Senhora ou a outros santos. O desejo era de controlar a vivência religiosa. Desterro realçava, numa pastoral de abril de 1747, que sua intenção não era coibir as devoções particulares, mas era de sua obrigação buscar extirpar tudo o que fosse contrário ao bom serviço de Deus. ${ }^{18}$

Os prelados jacobeus haviam notado que, do ponto de vista da busca por uma reforma cristã dos costumes, a escravidão era responsável por alguns dos principais problemas que afligiam a sociedade luso-americana. Embora jamais tenham se posicionado contra a escravidão africana, os bispos fluminenses insistiram em pastorais e capítulos de visitas que as pessoas escravizadas eram católicas e, por essa razão, deveriam receber os sacramentos e esperar a recompensa da vida eterna. Isto, muitas vezes, implicou exigir dos senhores de escravos uma conduta condizente com a religião que professavam. Aqueles que contribuíam para afastar os escravos de uma vida cristã precisavam ser responsabilizados por isso nos tribunais eclesiásticos, pois, seguramente, o seriam no tribunal divino.

Outro problema constante foram os enterramentos indevidos. Na carta pastoral de maio de 1742, D. Frei João da Cruz repreendia, sob pena de excomunhão, os senhores por não comunicarem aos párocos as enfermidades dos seus escravos e a necessidade de administrarem os sacramentos da penitência, eucaristia e da extrema-unção. Aos senhores, recordava a importância de encomendar as almas dos seus escravos e frisava não ser "bem que servindo-se deles em vida senão lembrem deles na morte". Nesse ponto, reaparece o desejo do bispo de controlar e enquadrar os comportamentos e as devoções, proibindo a permanência das irmandades quando os párocos levavam o viático aos enfermos.

D. Frei Antônio do Desterro foi ainda mais contundente quanto aos sepultamentos indevidos. Em edital lançado em 15 de abril de 1747, acusava os senhores de escravos de "inumanidade" por descartar os corpos dos escravos, sem 
o cuidado de administrar os últimos sacramentos e enterrá-los em solo sagrado, jogando-os no campo e vala da cidade "como se fossem irracionais". Essas ações, "que nem em bárbaros se experimentam", mereciam todo o castigo, pois aqueles que se diziam católicos não poderiam servir-se dos escravos em vida e, no fim, "tratarem-nos como brutos e ainda faltarem-lhes com uma pobre mortalha". Anos depois, em carta pastoral de janeiro de 1754, Desterro retomava o tópico do enterro impróprio, ressaltando a "impiedade" daqueles que abandonavam os corpos dos escravos mortos sem receber a extrema-unção, sem mortalha e sem comunicar os párocos. Algumas vezes, dizia, achavam os corpos "despedaçados pelos cães". Era "aborrível e lamentável que um miserável escravo" tendo servido o seu senhor toda a vida, "seja este tão ímpio e bárbaro que nem sepultura lhe mande dar, nem encomendar a sua alma e depois de morto expondo um cadáver cristão, cuja alma pode estar gozando da bem-aventurança eterna”. A vigilância sobre os negligentes pertencia novamente aos párocos que deveriam cotejar os róis da desobriga, verificar se algum escravo faleceu sem os ofícios devidos e impedir os senhores remissos de comungar na Quaresma. As pastorais, entretanto, não lograram absoluto sucesso pois, em agosto de 1765, Desterro rememorava não ser a primeira vez que constatava a falta de humanidade e caridade dos senhores que jogavam "nos monturos e lugares não sagrados os corpos dos escravos como se foram de brutos, animais", chegando a largarem, certa vez, na porta do palácio episcopal, "o corpo de um preto sem mais mortalha, que o tecido de umas palhas" ${ }^{19}$

É evidente que boa parte das preocupações dos bispos fluminenses, como notado anteriormente por Ana Margarida Pereira ao tratar das medidas tomadas por Desterro, era de cariz espiritual (Pereira, 2014, p. 290-292). As medidas visavam, sobretudo, corrigir a ineficiente assistência espiritual dada aos escravos, o acesso aos sacramentos, e a de garantir, por fim, a salvação das suas almas. Sob essa perspectiva compreende-se a inquietação de D. Frei Antônio do Desterro na carta pastoral de 20 de maio de 1758, quando advertiu os senhores de escravos a darem dinheiro ou os meios legais para que os "miseráveis escravos" adquirissem "um tesouro tão grande" como era a Bula da Santa Cruzada, que concedia indulgências aos católicos que dessem as esmolas estipuladas pelo diploma pontifício. ${ }^{20}$

\section{CONSIDERAÇÕES FINAIS}

Ao final deste artigo, algumas conclusões se impõem sobre o exercício do governo episcopal fluminense pelos bispos jacobeus. O maior uso de cartas 
pastorais, o reforço das visitas diocesanas, realizadas com mais frequência e rigor do que nos governos antecedentes,$^{21}$ além de exames sinodais mais exigentes, denotam o incremento das políticas de disciplinamento do clero diocesano que se constituiu na ponta de lança do enquadramento religioso da população.

Reitera-se a percepção de que não se deve entender o caráter inflexível e conflituoso como inerente aos prelados vinculados à Jacobeia. Não obstante o rigorismo jacobeu, os bispos aqui analisados buscaram administrar a diocese sem entrar em conflitos com as autoridades civis e, sempre que possível, evitaram maiores confrontos nas medidas tomadas com vistas ao acrisolamento do clero. Embora tenham manifestado, nalgumas ocasiões, claro desgosto em relação ao comportamento pouco cristão de muitos fiéis, a flexibilidade mostrada por esses prelados não deve ser entendida como capitulação. Ela foi, antes, o fruto dos conselhos das lideranças jacobeicas, a exemplo do cardeal João da Mota, que insinuavam a necessidade de compor politicamente com os governadores, de proceder com suavidade no seu objetivo reformador, sem tentar corrigir tudo ao mesmo tempo.

Embora tenham compartilhado da visão preconceituosa em relação aos negros e pardos - que era majoritária entre as elites -, o olhar dos prelados jacobeus sobre a população escravizada denota preocupação e compaixão. Nenhum deles questiona a escravidão, mas as severas críticas e advertências feitas aos senhores constituíam um esforço para a cristianização desses homens e mulheres escravizados. Tais ações, empreendidas com o intuito de salvar suas almas, podiam representar a abertura de espaços de negociação para os escravos, com ganhos efetivos no plano social.

\section{REFERÊNCIAS}

ALVES, Ana Maria M. R. "O Reyno de Deos e a sua justiça”: Dom Frei Inácio de Santa Teresa (1682-1751). 2012. Tese (Doutorado em História) - Faculdade de Letras, Universidade de Coimbra. Coimbra, 2012.

ANNUNCIAÇÃO, Francisco da. Vindicias da virtude e escarmento de virtuosos nos públicos castigos dos hipócritas dados pelo Tribunal do santo Oficio. Lisboa: Na officina Ferreiriana, 1725-1726. 3 v.

BANDEIRA, Ana Maria L. "Mano muito do meu coração...": Reconstituição do arquivo pessoal de D. Francisco de Lemos e transcrição das cartas de seu irmão João Pereira Ramos de Azeredo Coutinho (1775-1779). Boletim do Arquivo da Universidade de Coimbra, v. XXX, p. 35-160, 2017. 
BLUTEAU, Rafael. Vocabulario Portuguez e latino... Vol. 9. Lisboa: Officina de Pascoal da Sylva, Impressor de Sua Magestade, 1728.

BRITTO, Michelle Carolina de. "Com poder e jurisdição": conflitos jurisdicionais na construção da diocese de São Paulo (1682-1765). 2018. Dissertação (Mestrado em História) - Universidade Federal de São Paulo (Unifesp). Guarulhos, 2018.

FERREIRA, Fernanda V. O clero secular no bispado do Rio de Janeiro e o múnus episcopal de D. Francisco de São Jerônimo. 2016. Dissertação (Mestrado em História) - Universidade Federal do Estado do Rio de Janeiro (UniRio). Rio de Janeiro, 2016. GUADALUPE, D. Frei Antônio de. Sermoens do excelentíssimo e reverendíssimo D. Fr. Antonio de Guadalupe... T. 1. Lisboa: Na Officina dos Herdeiros de Antonio Pedrozo Galram, 1749.

MENDES, Ediana Ferreira. Da Universidade de Coimbra ao Brasil: os bispos da Baía, de Olinda e do Rio de Janeiro (1676-ca.1773). 2018. Tese (Doutorado em História) - Faculdade de Letras, Universidade de Coimbra. Coimbra, 2018.

LARA, Silvia H. Fragmentos setecentistas: escravidão, cultura e poder na América portuguesa. São Paulo: Companhia das Letras, 2007.

PAIVA, José Pedro. Baluartes da fé e da disciplina: o enlace entre a Inquisição e os bispos em Portugal (1536-1750). Coimbra: Imprensa da Universidade de Coimbra, 2011.

PAIVA, José Pedro. Os bispos de Portugal e do Império (1490-1777). Coimbra: Imprensa da Universidade de Coimbra, 2006.

PAIVA, José Pedro. Reforma religiosa, conflito, mudança política e cisão: o governo da diocese de Olinda (Pernambuco) por D. Fr. Luís de Santa Teresa (1738-1754). Revista de História da Sociedade e da cultura, Coimbra, n. 8, p. 161-210, 2008.

PEREIRA, Ana Margarida S. A legislação sobre escravos no episcopado de D. Frei António do Desterro, Rio de Janeiro (1747-1773). In: OLIVEIRA, Anderson; MARTINS, William (org.). Dimensões do Catolicismo no Império Português (Séculos XVI-XIX). Rio de Janeiro: Garamond, 2014. p. 267-295.

QUANTIN, Jean-Louis. Le Rigorisme chrétien. Paris: Cerf, 2001.

RAMINELLI, Ronald. Nobrezas do Novo Mundo: Brasil e ultramar hispânico, séculos XVII e XVIII. Rio de Janeiro: Ed. FGV, 2015.

RODRIGUES, Mons. Flávio Carneiro. As visitas pastorais do século XVIII no bispado de Mariana. Mariana, MG: Ed. Dom Viçoso, 2004.

SALES SOUZA, Evergton. Jansénisme et Réforme de l'Eglise dans l'Empire portugais. Paris: Centre Culturel Calouste Gulbenkian, 2004.

SALES SOUZA, Evergton. D. Fr. Antônio de Guadalupe, um bispo jacobeu no Rio de Janeiro (1725-1740). Via Spiritus, Porto, v. 22, p. 137-165, 2015.

SANTOS, Patrícia F. dos. Poder e palavra: discursos, contendas e direito de padroado em Mariana (1748-1764). São Paulo: Hucitec, 2011. 
SILVA, Antônio P. da. A questão do sigilismo em Portugal no século XVIII: história, religião e política nos reinados de D. João V e D. José I. Braga: Tip. Ed. Franciscana, 1964.

SOARES, Kate Dayane A. O governo episcopal de Dom Frei Manuel da Cruz no bispado do Maranhão (1739-1747). 2016. Dissertação (Mestrado em História) - ICHF, Universidade Federal Fluminense (UFF). Niterói, 2016.

TORRES-LONDOÑO, Fernando. A outra família: concubinato, Igreja e escândalo na colônia. São Paulo: Loyola, 1999.

TRINDADE, Ana Cristina M. O Episcopado de D. Frei Manuel Coutinho, 1725-1741. 2014. Tese (Doutorado em História) - Faculdade de Letras, Universidade da Madeira. Funchal, 2014.

VIANA, Larissa M. O idioma da mestiçagem: as irmandades de pardos na América portuguesa. Campinas: Ed. Unicamp, 2007.

VIEIRA, Pe. Antônio. Sermões do P. Antonio Vieira da Companhia de Iesu, Prégador de Sua Magestade. Quarta parte. Lisboa: Na Officina de Miguel Deslandes, 1685.

\section{NOTAS}

${ }^{1}$ Este artigo resulta de pesquisas realizadas no âmbito dos projetos "Jacobeia e ação reformadora dos bispos jacobeus na América portuguesa (Século XVIII)" e "Disciplinando almas, disciplinando a sociedade: o cristianismo no Império português", financiados pelo CNPq e coordenados por Evergton Sales Souza, e "Religião, administração e justiça eclesiástica no império português (1514-1750) - ReligionAJE”, PTDC/HAR-HIS/28719/2017, financiado pela FCT-Portugal e coordenado por José Pedro Paiva (Universidade de Coimbra).

${ }^{2}$ Arquivo Nacional da Torre do Tombo (ANTT), Tribunal do Santo Ofício, Conselho Geral, Habilitações Incompletas, doc. 741, e Antonio do Sacramento, Hystoria serafica, chonologica da Ordem de S. Francisco na Provincia de Portugal da regular observância. Lisboa. No anno de 1768, Manuscritos da Livraria, número 703.

${ }^{3}$ Archivio Segreto Vaticano (ASV), Congregazione del Concilio, Relationes Dioecesium, 729 (Fluminis Januarii), folhas sem numeração.

${ }^{4}$ Arquivo da Cúria Metropolitana do Rio de Janeiro (ACMRJ), Série Encadernado, Livro de Pastorais e Editais (1742-1838), livro E-236, f. 8v-13.

${ }^{5}$ ASV, Archivio Concistoriale, Processus Consistoriales, vol. 124, f. 37-41 e Acta Camerarii, vol. 31, f. 187v.

${ }^{6}$ ACMRJ, Série Encadernado, Livro de Pastorais e Editais (1742-1838), livro E-236, f. 3232v, f. 40v-42 e Livro de Portarias e Ordens (1750-1761), livro E-238, f. 11-32.

${ }^{7}$ Arquivo Histórico Ultramarino (AHU), Minas Gerais Avulsos, cx. 43, doc. 3571. 
${ }^{8}$ AHU, Rio de Janeiro, Castro e Almeida, cx. 70, doc. 16251.

${ }^{9}$ AHU, Rio de Janeiro Avulsos, cx. 16, doc. 1808.

${ }^{10}$ AHU, Minas Gerais Avulsos, cx. 43, doc. 3571.

${ }^{11}$ AHU, Rio de Janeiro, Castro e Almeida, cx. 84, doc. 19465 e cx. 84, doc. 19479.

${ }^{12}$ De cor trigueira eram outros membros da família Azeredo Coutinho. Silvia Lara apresenta o caso de um filho do capitão Inácio Rangel de Azeredo Coutinho, comerciante de gado que se meteu em disputa com um alferes. O comerciante em suas alegações junto à justiça lembrava que "o acidente da cor não tira nobreza a quem a tem por seus pais" (LARA, 2007, p. 138).

${ }^{13}$ Sobre a questão dos pardos na América portuguesa, abordada aqui tangencialmente, ver o estudo de Larissa Viana (VIANA, 2007).

${ }^{14}$ AHU, Rio de Janeiro, Avulsos, cx. 16, doc. 1808.

${ }^{15}$ AHU, Minas Gerais, Avulsos, cx. 43, doc. 3571.

${ }^{16}$ Esta preocupação também era mencionada nas provisões dos vigários encomendados do Rio de Janeiro, nas quais se dizia que o vigário deveria ensinar a doutrina "principalmente aos pequenos e pessoas rudes”. AHU, Rio de Janeiro, Avulsos, cx. 104, d. 8834. Nestas disposições sobre os escravos, é importante notar, seguia-se o disposto nas Constituições do arcebispado da Bahia.

${ }^{17}$ ACMRJ, Série Encadernado, Livro de Pastorais e Editais (1742-1838), livro E-236, f. 9-11v (carta pastoral de D. Frei João da Cruz) e f. 45v-49 (carta pastoral de D. Frei Antônio de Guadalupe).

${ }^{18}$ ACMRJ, Série Encadernado, Livro de Portarias e Ordens (1750-1761), livro E-238, f. 62v-64v, 66-66v e Livro de Pastorais e Editais (1742-1838), livro E-236, f. 35-36, f. 107-108v.

${ }^{19}$ ACMRJ, Série Encadernado, Livro de Pastorais e Editais (1742-1838), livro E-236, f. 11v12 (Carta pastoral de D. Frei João da Cruz) e f. 37v, 80-80v e f. 110-110v (editais e cartas pastorais de D. Frei Antônio do Desterro.

${ }^{20}$ ACMRJ, Série Encadernado, Livro de Pastorais e Editais (1742-1838), livro E-236, f. 89-90.

${ }^{21}$ Estudos como os de Torres-Londoño (TORRES-LONDOÑO, 1999, p. 123-131) e Fernanda V. Ferreira (FERREIRA, 2016) parecem corroborar esse ponto de vista.

Artigo recebido em 15 de julho de 2019.

Aprovado em 1ํ de novembro de 2019.

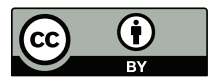

